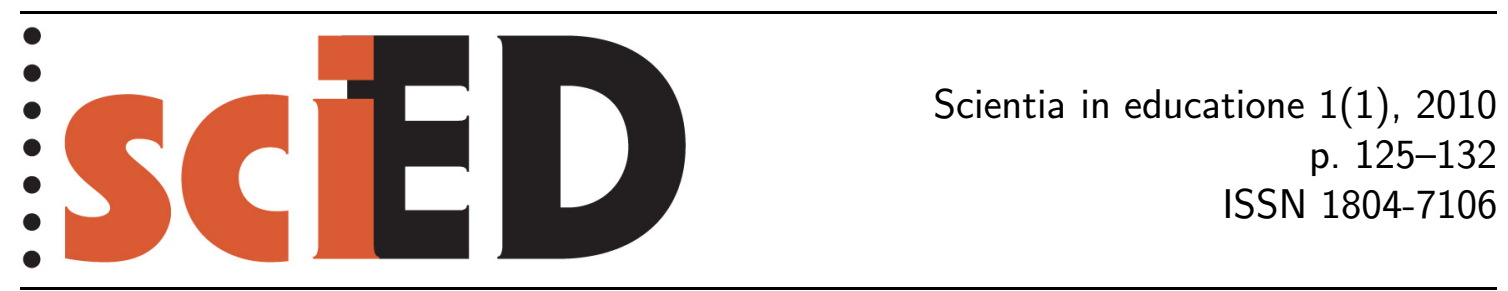

\title{
Didaktika biologie - vývoj a současnost
}

\section{Petr Dostál}

\begin{abstract}
Abstrakt
Článek popisuje vznik a vývoj didaktiky biologie u nás od poválečných let až po současnost. Věnuje se klíčovým osobnostem tohoto oboru a důležitým mezníkům jeho vývoje. Zdůrazňuje však také některé problémy, kterým současná didaktika biologie jako věda čelí. Je diskutována i historie spolupráce mezi Pedagogickou fakultou a Př́rodovědeckou fakultou Univerzity Karlovy v Praze na poli didaktiky biologie. Je podán přehled univerzitních učebnic a přednášek, které u nás byly publikovány od roku 1945.
\end{abstract}

Klíčová slova: didaktika biologie, historie, Univerzita Karlova v Praze, př́rodní vědy.

\section{Didactics of Biology - Development and Current State}

\begin{abstract}
The paper describes the foundation and development of didactics of biology in our country from post-war years to nowadays. It pays attention to the key figures in this field and important landmarks of its development. However, it also highlights some problems which exist in contemporary didactics of biology. The paper discusses the cooperation of the Faculty of Education and Faculty of Sciences at Charles University in Prague in the field of didactics biology. A survey of university textbooks and lecture notes of didactics of biology which have been published in our country since 1945 is given.
\end{abstract}

Key words: didactics of biology, history, Charles University in Prague, natural sciences. 
Čtyřicet pět let $\mathrm{v}$ životě člověka představuje téměř celou jeho aktivní, tvưrčí část. V historii vědního oboru je to však jen krátká epizoda, která však může v počáteční fázi formování jeho následný vývoj výrazně ovlivnit. A právě v tomto časovém rozpětí, které odpovídá mému působení na Pedagogické fakultě UK, bych chtěl poukázat na některé klíčové momenty v utváření didaktiky biologie a zmínit se i o významných osobnostech stojících v popředí tohoto dění. Pro úplnost bych uvedl též hlavní prvorepublikové a poválečné představitele nově vznikajícího oboru, v té době označovaného nejčastěji jako metodika biologie či přírodopisu. Součástí příspěvku je v závěru i seznam literatury, jenž zahrnuje prakticky veškeré vysokoškolské učebnice, skripta a další práce z didaktiky biologie, které byly u nás po roce 1945 do roku 2001 vydány.

I když první metodiky přírodopisu byly zpracovány již koncem devatenáctého a začátkem dvacátého století (např. Nekuta, 1890; Kramář, 1905; Rosický, 1907), výraznější rozvoj didaktiky prrírodopisu nastává u nás až v období tzv. pedagogického reformismu (1920-1930) a je spojen zvláště se jmény J. Ulehla, A. Grác, J. Rosický, V. Příhoda a R. Šmika. Během protektorátu (1939-1945) dochází sice $\mathrm{v}$ našem školství $\mathrm{k}$ hlubokému úpadku, ale i v té době má česká didaktika přírodopisu své osobnosti, ke kterým patří především B. Valoušek, V. Bartušek a M. Fendrych.

Vývoj našeho školství (a tím i didaktiky) po roce 1945 byl ovlivněn Košickým vládním programem. V Praze, v Brně a v Bratislavě byly zřízeny Výzkumné pedagogické ústavy a při univerzitách pedagogické fakulty. V roce 1947 byl založen M. Fendrychem i první didaktický časopis Přírodověda a výchova, v roce 1950 pak vznikl časopis Přírodní vědy ve škole. V roce 1945 byla ustanovena celostátní komise pro zpracování nových osnov přírodopisu, jejíž biologickou složku vedl J. Šula. Didaktika biologie se začala rozvíjet zvláště zásluhou A. Vodičky, A. Gráce, O. Strumhause a V. Hajnera. První poválečnou vysokoškolskou učebnici didaktiky zpracoval A. Jungr (Jungr, 1964) a následnou pak B. Řehák (Řehák, 1965).

Osudy didaktiky biologie byly v prvních poválečných letech spojeny samozřejmě především s rozvojem institucí, které vysokoškolskou přípravu učitelů zajištovaly. V meziválečném období středoškolské učitele biologie připravovaly fakulty univerzit, na UK to byla od roku 1920 Př́rodovědecká fakulta, při které byl však zř́zen pouze lektorát metodiky s externisty - středoškolskými učiteli. V roce 1946 byly v českých zemích i na Slovensku při všech univerzitách zř́izeny pedagogické fakulty. Další změnu ale přinesl rok 1953, kdy byly pedagogické fakulty zrušeny a přípravu učitelů převzaly vyšší školy pedagogické a vzápětí i vysoké školy pedagogické. V roce 1959 přípravu středoškolských učitelů biologie opět přebírá př́rodovědecká fakulta a vzdělávání učitelů pro základní školy bylo svěřeno nově zřízeným pedagogickým institutům. Tato situace se přes mnohé dílčí reorganizace a reformy udržela až do roku 1964, kdy byla opět obnovena koncepce pedagogických fakult - jak při jednotlivých univerzitách, tak i pedagogických fakult samostatných, a to v krajích bez univerzit (Vorlíček, 1996).

Posláním tohoto příspěvku nemůže být samozřejmě podrobná historická analýza vývoje didaktiky biologie v celých poválečných českých zemích a na Slovensku. Rád bych se však zevrubněji věnoval alespoň situaci v Praze, přesněji na Pedagogické fakultě a Přírodovědecké fakultě Univerzity Karlovy, a to nejen proto, že jsem celé toto dění od roku 1965 jako člen katedry biologie a základů zemědělské výroby Pedagogické fakulty mohl dobře sledovat a aktivně se do něj zapojit, ale také proto, že mezi těmito dvěma jmenovanými fakultami probíhala ve sledovaném období na poli didaktiky biologie velmi úzká spolupráce. 
Intenzívní a koncepčně provázaná spolupráce mezi kabinetem vyučování biologie a chemie Př́rodovědecké fakulty (zřízen v roce 1962) a katedrou biologie a základı̊ zemědělské výroby Pedagogické fakulty UK byla do značné míry umožněna vedením jednou osobností - prof. RNDr. J. Langem, který byl pověřen zajištováním didaktické složky přípravy středoškolských učitelů biologie na Př́rodovědecké fakultě. Ve zmíněném kabinetu vykonával provozní úkoly přidělený asistent, později odborný asistent katedry učitelství a didaktiky biologie RNDr. J. Stoklasa (Stoklasa, 1971, 1972, 1975, 1977, 1978). V roce 1967 pak byl ustanoven již samostatný kabinet didaktiky biologie. V té době Pedagogická fakulta připravovala učitele pro 2. stupeň základních škol, a to pro předměty přírodopis a pěstitelské a chovatelské práce.V řadách jejích pracovníků stáli někteří významní didaktikové, především PhDr. A. Altmann a doc. RNDr. J. Macek, CSc. Toto společné a jednotné vedení obou kateder se projevovalo nejen vzájemnou výukou a vedením pedagogických praxí studentů, ale i spoluautorskou prací na učebnicích, učebních pomůckách a později též na přípravě a organizování prvních společných didaktických výzkumných projektů.

Prof. Lang byl hlavním autorem prvních učebnic didaktiky pro přírodovědecké fakulty (Lang a kol., 1963, 1970) a zároveň i iniciátorem a organizátorem prvních didaktických výzkumů u nás, které byly zaměřeny na problematiku vytváření teoretických a praktických vědomostí žáků na všeobecně vzdělávacích školách. Cenné na tomto výzkumu, který probíhal v letech 1967-1969, bylo i to, že nepostihoval pouze středočeský region včetně Prahy, ale díky spolupráci s doc. RNDr. O. Pravdou z Pedagogické fakulty v Českých Budějovicích i region jihočeský. Výsledky výzkumu byly pak publikovány ve sbornících pražské a českobudějovické pedagogické fakulty (Lang, 1969; Lang, Stoklasa, 1969). Z hlediska jeho rozsahu, použité metodiky i mezifakultní koordinace se jednalo o didakticko-biologický výzkum, který u nás nebyl do dnešní doby pravděpodobně překonán. Získané údaje byly připraveny i pro strojně početní zpracování, ale bohužel nedostatek financí tomu v poslední fázi zabránil. Rozsáhlý soubor dat by jistě s použitím zmíněné výpočetní techniky umožnil postihnout celou řadu dalších korelací a kvalitativních charakteristik. V této souvislosti je třeba připomenout i obdobně zaměřené výzkumy, které se uskutečnily v menším rozsahu již v letech 1962-1963 (Lang, 1964, 1966). Prof. Lang publikoval zároveň často v didaktickém časopise Prrírodní vědy ve škole a jako hlavní autor se podílel na tvorbě učebnic zoologie pro pedagogické instituty a pedagogické fakulty.

I když ve výuce odborným předmětům a ve výuce didaktikám na Př́rodovědecké fakultě UK docházelo k postupným změnám, které odpovídaly požadavkům na kvalitnější přípravu budoucích učitelů př́rodovědných předmětů, k zásadnímu zlomu došlo až po smrti prof. Langa (1972). Tehdy sloučením kabinetů didaktiky biologie, chemie a metodologie a dějin př́rodních věd byla ustanovena nová katedra didaktik, metodologie a dějin přírodních věd pod vedením doc. PhDr. F. Čížka, CSc. (Čížek a kol., 1978). Katedra usilovala o zvýšení úrovně pedagogicko-didaktické složky učitelské přípravy, a to zvláště zdůrazněním jednoty teoretických vědomostí budoucích učitelů a odborné přípravy z biologie a chemie. V oblasti vytváření učitelských dovedností šlo o maximální využití praktických cvičení z oborových didaktik jako předpokladu pro budoucí úspěšné pedagogické působení absolventů na školách. S výukou na fakultě byly provázány též pedagogické praxe na různých typech škol. Pracovníci katedry řešili společně rovněž některé otázky výzkumu v didaktikách, podíleli se na př́pravě osnov pro střední školy a na tvorbě učebnic i učebních pomůcek. V roce 1988 byla na Přírodovědecké fakultě UK ustavena samostatná katedra učitelství a didaktiky biologie, jejímž vedením byl pověřen doc. RNDr. F. Hor- 
ník, CSc. (Horník, 1988), což lépe umožňovalo plnit funkci koordinace složek odborné přípravy s př́pravou didaktickou, a to jak v pregraduálním a souběžném studiu, tak i v rámci př́pravných kurzů pro středoškoláky. V této tendenci pokračovala katedra v letech 1994-1998 pod vedením doc. RNDr. V. Čížkové, CSc., a v následujícím období pod vedením doc. PaedDr. et RNDr. M. Švecové, CSc., kdy se pozitivní posun ve vývoji katedry ještě zvýraznil.

K nejvýznamnějším osobnostem české didaktiky biologie jistě právem náleží prof. RNDr. J. Šula, vysokoškolský učitel na Přírodovědecké fakultě UP v Olomouci. Byl autorem nebo spoluautorem vynikajících učebnic botaniky (např. Šula, 1964), jako hlavní redaktor publikoval v časopise Přírodní vědy ve škole, pracoval v četných komisích pro tvorbu učebních plánů, osnov a učebnic, i v několika redakčních radách. Ve svých teoretických studiích se zabýval především problematikou vytváření pojmů. Známé je též jeho kritické stanovisko k označení předmětu „přírodopis" na ZDŠ, které přetrvalo ale až do dnešní doby. S jeho osobou je spojena především snaha o založení a rozvinutí didaktiky biologie jako jedné z plnohodnotných vědních disciplín. Za tímto účelem byl proto na podzim v roce 1967 svolán na Pedagogickou fakultu v Nitře celostátní seminář didaktiků př́rodopisu a biologie, kterého se zúčastnili zástupci téměř všech pedagogických a př́rodovědeckých fakult Československa. Jedním z důležitých závěrů jednání bylo usnesení, které přriřadilo didaktice biologie, i přes její nespornou interdisciplinární povahu, místo mezi pedagogickými vědami. Důvodem $\mathrm{k}$ tomu byly zejména předmět a používaná metodika didaktického výzkumu.

Nejrozsáhlejší publikační činnost v oblasti didaktiky přírodopisu a biologie je svázána s osobou PhDr. A. Altmanna, vysokoškolského učitele katedry biologie a základů zemědělské výroby Pedagogické fakulty UK. Během svého třicetiletého působení ve zmíněné instituci zpracoval kompletní soubor učebnic a skript pro studenty pedagogických fakult (Altmann, 1966, 1971, 1972, 1974, 1975) a na mnohých dalších se podílel jako spoluautor. Byl také dlouholetým členem redakční rady časopisu Přírodní vědy ve škole, ve kterém velmi často publikoval. Výrazný byl jeho příspěvek v práci na učebnicích pro základní a střední školy, na tvorbě učebních pomůcek a na bibliografickém zpracování bibliografické časopisecké literatury (např. Altmann a kol., 1976).

$\mathrm{K}$ významným osobnostem české didaktiky se řadí i doc. RNDr. J. Macek, CSc., do roku 1976 vedoucí oddělení základů zemědělské výroby katedry biologie a Zzv na Pedagogické fakultě UK. Byl jedním z prvních, kteří se u nás habilitovali v oboru teorie vyučování biologii, publikoval v didaktických časopisech, podílel se na tvorbě učebnic pro střední školy a jako hlavní autor je uveden na vysokoškolské učebnici metodiky pěstitelských a chovatelských prací (Macek a kol., 1966). V této oblasti později publikovala též jeho spolupracovnice doc. ing. J. Vodáková, CSc. (Vodáková, 1990). Jako zkušený pedagog zasáhl doc. Macek i do reforem a př́prav nových koncepcí československého a českého školství.

Na Pedagogické fakultě UK působila do roku 1979, kdy bylo učitelské studium př́rodopisu na patnáct let definitivně uzavřeno, celá řada dalších vynikajících učitelů, kteří se ve zvýšené míře věnovali didaktické problematice. $\mathrm{Z}$ nich je nutné jmenovat alespoň PhDr. H. Střihavkovou, RNDr. E. Liškovou, CSc., RNDr. E. Kočárka, CSc., RNDr. M. Hajnišovou, CSc., a PhDr. E. Komanovou, CSc. V roce 1994 se podařilo za nemalého úsilí všech bývalých pracovníků původní katedry obnovit oborové studium učitelství přírodopisu a biologie a vedením katedry biologie a ekologické výchovy byl pověren doc. $\mathrm{PhDr}$. P. Dostál, CSc., docent jmenovaný pro obor teorie vyučování biologii (Dostál, 1977, 
1982, 2001). V této době se opět rozvinula formou vzájemných přednášek, seminářů, exkurzí a společných grantů velmi intenzívní spolupráce s katedrou učitelství a didaktiky biologie Přírodovědecké fakulty UK a tato tendence pokračovala i za nového vedoucího katedry doc. RNDr. V. Zieglera, CSc., kdy se spolupráce rozššrilia též na geologickou sekci Př́rodovědecké fakulty.

Didaktika biologie se rozvíjela i na dalších pedagogických a prrírodovědeckých fakultách v českých zemích a na Slovensku. Na Přírodovědecké fakultě UJEP v Brně to bylo především zásluhou RNDr. F. Dvořáka, CSc. (Dvořák, 1981), na Přírodovědecké fakultě Univerzity Komenského v Bratislavě pak také působil RNDr. L. Oldriš, CSc. (Oldriš, 1992) a dnes se tomuto oboru věnuje především doc. RNDr. K. Ušáková, CSc. (Ušáková, 1990).

Formování oborových didaktik (též někdy označovaných jako „speciální didaktiky“) bylo a je samozřejmě spojeno s možností dalšího graduačního růstu vysokoškolských pedagogů i postgraduálního vzdělávání nových absolventů učitelského studia. Od roku 1968 bylo proto možné obhájit rigorózní práci a vykonat státní rigorózní zkoušky také v oboru teorie vyučování biologii, a to před společnou komisí Pedagogické a Přírodovědecké fakulty UK. Rozdíl byl pouze v získaném akademickém titulu, kdy pro absolventy pedagogických fakult byl určen titul PhDr., pro absolventy přírodovědeckých fakult pak titul RNDr. Také pro dosažení vědecké hodnosti byla otevřena cesta přípravou v oboru teorie vyučování biologii, jenž však spadal do kompetence komisí pro kandidáty pedagogických věd. Habilitační, později pak jmenovací ř́zení docentů probíhalo též v oboru teorie vyučování biologii. Vybrané kapitoly z didaktiky biologie (zvláště aktivizující metody a organizační formy výuky) byly začleněny i do postgraduálního studia učitelů, které museli učitelé do deseti let po ukončení vysoké školy absolvovat.

Podpůrnou funkci v rozvoji didaktiky biologie a v udržování kontaktu mezi učiteli všeobecně vzdělávacích škol a vysokými školami sehrával po řadu let i náš jediný již zmíněný didakticky zaměřený časopis Přírodní vědy ve škole. Byl založen v roce 1950 a vycházel až do roku 1990, kdy musel být z ekonomických důvodů zrušen. Na redakčním vedení tohoto časopisu se podílely mnohé významné osobnosti didaktiky biologie (např. Šula, Altmann), ale na jeho stránkách často publikovali i učitelé z praxe. V roce 1991 se podařilo značným úsilím několika jedinců ve spolupráci s nakladatelstvím SPN a Fortuna zahájit vydávání nového časopisu pro učitele přírodopisu, biologie, chemie a zeměpisu nazvaného Biologie, chemie, zeměpis, který však vychází ve srovnání s předchozím časopisem ve velmi skromných podmínkách. Prezentování školské a didaktické problematiky umožňují rovněž semináře organizované pedagogickou sekcí Biologické společnosti. Nezanedbatelný je i podíl vysokoškolských didaktiků na tvorbě učebnic pro základní a střední školy, na prř́pravě podkladů pro státní maturity i na práci s talentovanými žáky a studenty (Natura Semper Viva, biologické olympiády, SOČ apod.). Učinná byla v tomto smyslu i úzká spolupráce didaktiků a dalších vysokoškolských učitelů s Pedagogickými centry, která umožňovala formou přednášek, seminářů, exkurzí a publikací bezprostředně působit na učitele př́rodopisu a biologie v praxi.

Od roku 1967, kdy byl svolán do Nitry první poválečný seminář didaktiků biologie (zmíněn již v souvislosti s osobností prof. Suly), se podobných akcí uskutečnilo velmi málo. V ř́jnu roku 1981 se konala na PedF UK konference Speciální didaktiky jako vědní obory a jako studijní předměty (Speciální didaktiky, 1982), kde kromě obecněji pojatých sekcí získaly svůj prostor i tzv. sekce „,speciálních didaktik" s příspěvky pracovníků přírodovědných kateder pedagogické fakulty a přírodovědeckých fakult. Další významnější akcí v tomto směru byla v roce 1998 
konference Nové trendy vzdělávání učitelů př́írodovědných oborů, která se konala u př́ležitosti 25. výročí vzniku katedry didaktik na Přírodovědecké fakultě UK (Nové trendy, 1998). V roce 1997 otevřela Pedagogická fakulta UK cyklus seminářu Problémy oborových didaktik jako vědních disciplin a jako předmětů studia budoucích učiteli̊. Na podzim následujícího roku se v rámci tohoto cyklu uskutečnil seminář Současnost a perspektivy didaktiky biologie, jehož cílem bylo především informovat přítomné zástupce pedagogických a přírodovědeckých fakult o směrech a stavu výzkumných aktivit a záměrů na PedF a PřF UK v Praze. Dílčími problémy se zabývala i menší didakticky zaměřená konference Modernizace výuky biologie a geologie, která byla organizována ve spolupráci s Př́rodovědeckou fakultou na katedře biologie a ekologické výchovy Pedagogické fakulty UK v listopadu 1999. Kromě pracovníků obou fakult se jednání zúčastnili i fakultní učitelé základních a středních škol (Modernizace výuky, 2000). Za zmínku jistě stojí i setkání k 10. výročí vzniku katedry didaktiky na Prírodovedeckej fakultě Univerzity Komenského v Bratislavě. Přes všechny klady uvedených seminářů a konferencí je však potřeba konstatovat jeden jejich společný rys. Tím je často prakticistická a pragmatická povaha diskusních př́ispěvků, která mnohdy postrádá základ v teoretických pedagogicko-psychologických koncepcích.

Ve stručně podaném historickém pohledu na vývoj didaktiky biologie u nás (do roku 2001) jsem uvedl celou řadu pozitivních momentů, které kladně zasáhly do formování našeho základního, středního i vysokého školství. Neznamená to však, že stále neexistují některá vážná úskalí, která bude nutné pro zachování a další rozvoj tohoto vědního oboru společným úsilím překonat. Jistě si nikdo z nás nepřeje, aby úsvit třetího tisíciletí byl zároveň soumrakem didaktiky biologie. $\mathrm{K}$ významnému počinu v této oblasti proto patří, že se konečně po mnoha pokusech podařilo v roce 2010 ve spolupráci Pedagogické fakulty UK v Praze a Přírodovědecké a Pedagogické fakulty JU v Českých Budějovicích akreditovat doktorské studium „Vzdělávání v biologii“, které v budoucnu umožní habilitace, popř. i profesorská řízení $\mathrm{v}$ tomto potřebném oboru.

\section{LITERATURA}

ALTMANN, A. Didaktické zásady ve výuce biologii. [skripta PedF UK] Praha : SPN, 1971.

ALTMANN, A. Metody a zásady ve výuce biologii. Praha : SPN, 1975.

ALTMANN, A. Organizační formy ve výuce biologii [skripta PedF UK]. Praha: SPN, 1972 .

ALtmanN, A. Pomůcky pro výuku biologii. Praha : SPN, 1971.

ALTMANN, A. Př́rodniny ve vyučování př́rodopisu a biologii. Praha : SPN, 1966.

ALTMANN, A. Úvod do didaktiky biologie[skripta PedF UK]. Praha : SPN, 1974.

ALTMANN, A. Vyučovací metody ve výuce biologii. Praha: SPN, 1971.

ALTMANN, A.; DOSTÁL, P. Bibliografie časopisecké literatury z didaktiky biologie v SSSR. [skripta PedF UK] Praha : Pedagogická fakulta UK, 1976.

ALTMANN, A.; HORNÍK, F. Vybrané kapitoly z didaktiky biologie. I., II. [skripta PřF UK] Praha: SPN, 1985. 
ČİŽEK, F. aj. Úvod do speciálních didaktik př́rodovědných předmětů. [skripta PřF UK] Praha : SPN, 1978.

DOSTÁL, P. Teoretické problémy výběru a zpracování obecně biologických poznatkư v systému učiva. [disertační práce] Praha : Pedagogická fakulta UK, 1977.

DOSTÁL, P. Význam názornosti pro trvalost osvojených vědomostí ve vyučování botanice na ZDŠ. In Sbornik PedF UK - Biologie IV. Praha : PedF UK, 1975, s. $55-61$.

DOSTÁL, P. Didaktika biologie na počátku 3. tisíciletí. In Sborník z mezinárodní konference 11. 9.-13. 9. 2001. „Didaktika biologie a didaktika geologie - současnost a perspektivy“. Praha : PřF UK, 2001, s. 7-12.

DVOß̌ÁK, F. aj. Základy didaktiky biologie. [skripta RUJEP] Brno : RUJEP, 1981.

FAUSTUS, L.; POLÍVKA, F. Botanický klíč. Praha : SPN, 1976.

HORNÍK, F.; ALTMANN, A. Vybrané kapitoly z didaktiky III. [skripta PřF UK] Praha : SPN, 1988.

JUNGR, A. aj. Metodika př́rodopisu. Praha : SPN, 1964.

KOMAnOVÁ, E. Didaktika př́rodovědy. [skripta PedF UK] Praha : SPN, 1985.

KRAMÁr̆, O. O př́rodních vědách na středních školách. Praha : 1905.

LANG, J. aj. Biologická školní technika. [skripta PřF UK] Praha : SPN, 1963.

LANG, J. aj. Problematika praktických znalostí biologických objektů žáků ZD a $S V V \breve{S}$. [sborník PedF ČB] In Práce PedF České Budějovice : Pedagogická fakulta, 1971.

LANG, J. aj. Vybrané kapitoly z didaktiky biologie. [skripta PřF UK] Praha : SPN, 1970.

LANG, J. Problematika ve vyučování zoologie na všeobecně vzdělávacích školách ZDS̆ a SVVŠ. In Sbornik Biologie I. Praha : PedF UK, 1969, s. 63-122.

LANG, J. Problematika ve vyučování zoologie na ZDŠ. I. část. In Sborník biol. a geol. věd. České Budějovice : PedF., 1964, s. 23-73.

LANG, J. Problematika ve vyučování zoologie na ZDŠ. II. část. In Sborník biol. a geol. věd. České Budějovice : PedF, 1966, s. 31-72.

LANG, J.; STOKLASA, J. K problematice výuky biologie na všeobecně vzdělávacích a odborných školách. In Sbornik Biologie II. Praha : PedF UK, 1969, s. 159-166.

MACEK, J. aj. Metodika pěstitelských a chovatelských prací. Praha : SPN, 1966.

MODERNIZACE VÝUKY biologie a geologie. Sborník př́spěvků z konference pořádané Pedagogickou a Př́rodovědeckou fakultou UK v Praze v rámci grantu FRVS̆ č. 1420/99 dne 10. listopadu 1999. Praha : UK - Ped. fakulta, 2000.

NEKUTA, F. Metodika př́rodopisu pro středni školy. Praha : 1890.

NOVÉ TRENDY vzdělávání učitelů přírodovědných oborů. Sborník přednášek. Praha : Karolinum, 1998.

ONDRIŠ, L. Školská biologická technika. [skripta PRIF UK] Bratislava : PRIF UK, 1992. 
ROSICKY, J. Metodika přírodopisu pro ústavy učitelské. Praha : 1907.

ŘEHÁK, B. Vyučování biologii. Praha: SPN, 1965.

SPECIÁLNÍ DIDAKTIKY jako vědní obory a jako studijní předměty. Sborník PedF UK. Praha : ORBIS PedF UK, 1982.

STOKLASA, J.; HORNÍK, F. Didaktika biologie a výuka biologie na gymnáziu. [skripta PřF UK] Praha: SPN, 1977.

STOKLASA, J.; HORNÍK, F.; KOČÁREK, E. Vytváření didaktických dovedností učitele biologie. [skripta PřF UK] Praha : SPN, 1984.

STOKLASA, J. Didaktická technika a ostatní prostředky ve výuce biologie. [skripta PřF UK] Praha : SPN, 1971.

STOKLASA, J. Fotografování biologických objektů a ostatní zpưsoby dokumentace pro potreby biologa. [skripta PřF UK] Praha : SPN, 1972.

STOKLASA, J. Kurs didaktické techniky pro učitele. [metodický materiál] Chomutov : OŠ ONV, 1975.

ŠULA, J. Botanika pro 6. ročník ZDS̆. Praha : SPN, 1964.

ŠVECOVÁ, M. Jednotlivé složky výuky v přípravě budoucích učitelů biologie ve vztahu k pedagogické praxi. In Pedagogická praxe - pedagogická praxeologie. [sborník z konference] Praha : PedF UK, 1997, s. 74-77.

ŠVECOVÁ, M. aj. Cvičení z didaktiky I. [skripta PřF UK] Praha : Karolinum, 2000.

ŠVECOVÁ, M. Možnost inovací struktury biologického učiva v návaznosti na dynamický rozvoj př́rodních věd. Pedagogika, 2001a, roč. 51, č. 3, s. 277-286.

ŠVECOVÁ, M. Teorie a praxe zařazení školních projektů ve výuce př́rodopisu, biologie a ekologie. [skripta PřF UK] Praha : Karolinum, 2001b.

UŠÁKOVÁ, K. Základy didaktiky biológie. [skripta PRIF UK] Bratislava : UK, 1990.

UŠÁKOVÁ, K. Vybrané kapitoly zo špeciálnej didaktiky biológie. [skripta PRIF UK] Bratislava : UK 1998.

VODÁKOVÁ, J. aj. Pěstitelské práce. Praha : SPN, 1990.

VORLÍČEK, CH. Z historie Pedagogické fakulty Univerzity Karlovy. Praha : PedF UK, 1996.

ZIEGLER, V. (ed.). Modernizace výuky biologie a geologie. [sborník př́íspěvků] Praha : PedF UK, 2000.

doc. PhDr. Petr Dostál, CSc. - E-mail: petr.dostal@pedf.cuni.cz

Univerzita Karlova v Praze, Pedagogická fakulta

katedra biologie a environmentálních studií, Česká republika 